\title{
PEMAHAMAN KONSEP BILANGAN BULAT GURU SD DI PASIR JAMBU - KABUPATEN BANDUNG
}

\author{
Didi Permana (didi-permana@ut.ac.id) \\ Tatang Herman \\ Universitas Terbuka
}

\begin{abstract}
This study aimed to identified the understanding of whole number concept among elementary school teacher taking distance course in Elementary Teacher Training - Indonesia Open University as viewed from the quality of module, tutor performance, and learning motivation. Samples were 72 participants of tutorial program under Mathematics for Elementary School subject carried out in Pasir Jambu village - Bandung Regency during 2012.1 registration period. Using questionaire, test concerning whole number concept, documentary study, observation and interview for data gathering. Results indicated that (i) module quality, tutor performance, and motivation contributed significantly toward whole number concept, the contribution number were $29,80 \%, 18,30 \%$ dan $29,80 \%$, (ii) module quality and tutor performance contributed significantly to whole number concept $(36,70 \%)$, (iii) tutor performance and motivation contributed significantly to whole number concept (38,70\%), (iv) module quality, tutor performance and motivation contributed significantly to whole number concept $(51,50 \%)$, and $(v)$ the rest $48,50 \%$ was determined by unidentified variables. Recommends that tutorial administrator should maintain the quality of module and to enlarge student access upon learning material through media alternative, to improve tutor profesionalism, and to encourage motivation among student concerned.
\end{abstract}

Keywords: modul, motivation, performance, whole number concept

\begin{abstract}
ABSTRAK
Penelitian ini bertujuan mengidentifikasi pemahaman tentang konsep bilangan bulat kelompok guru SD peserta pendidikan guru jarak jauh ditinjau dari aspek kualitas modul, kinerja tutor dan motivasi belajar. Sampel adalah seorang tutor dan 72 mahasiswa peserta tutorial mata kuliah Pembelajaran Matematika SD di Kelompok Belajar Pasir Jambu Kabupaten Bandung masa registrasi 2012.1. Pengumpulan data dilaksanakan menggunakan angket, tes pemahaman konsep bilangan bulat, studi dokumentasi, observasi dan tes untuk tutor. Hasil penelitian menunjukkan bahwa (i) kualitas modul, kinerja tutor dan motivasi belajar secara bersama-sama berkontribusi secara signifikan terhadap pemahaman konsep bilangan bulat, yaitu masingmasing sebesar 29,80\%, 18,30\% dan 29,80\%, (ii) kualitas modul dan kinerja tutor secara bersama-sama berkontribusi signifikan (36,70\%) terhadap pemahaman konsep bilangan bulat, (iii) kinerja tutor dan motivasi belajar mahasiswa secara bersama-sama berkontribusi secara signifikan (38,70\%) terhadap pemahaman konsep bilangan bulat, (iv) kualitas modul, kinerja tutor dan motivasi belajar mahasiswa bersama-sama berkontribusi secara signifikan (51,50\%) terhadap pemahaman konsep bilangan bulat, dan (v) sisanya 48,50\% ditentukan oleh variabel lain yang tidak diteliti. Disarankan hendaknya penyelenggara tutorial mempertahankan kualitas dan memperluas akses mahasiswa terhadap materi belajar, meningkatkan profesionalitas tutor, dan meningkatkan motivasi mahasiswa peserta tutorial.
\end{abstract}

Kata-kata kunci: kinerja, konsep bilangan bulat, modul, motivasi 
Sistem pembelajaran jarak jauh adalah pembelajaran yang menekankan pada cara belajar mandiri (self study) (Dogmen dalam Munir 2009), yaitu sistem belajar yang diorganisasikan secara sistematis dalam penyajian materi pembelajaran, pemberian bimbingan bagi pembelajar, dan pengawasan bagi upaya keberhasilan belajar. Dalam UU Republik Indonesia No. 20 Tahun 2003 disebutkan bahwa pendidikan jarak jauh berfungsi memberikan layanan kepada masyarakat yang tidak dapat mengikuti pendidikan secara tatap muka atau reguler.

Tutorial merupakan salah satu bentuk bantuan belajar bagi mahasiswa praktisi belajar mandiri yang mengikuti perkuliahan di UT. Salah satu bentuk tutorial adalah tutorial tatap muka (TTM). Parisipasi mahasiswa dalam TTM harus diawali dengan persiapan belajar yang baik, karena tanpa kesiapan maka kegiatan tutorial tidak akan berjalan sesuai dengan yang diharapkan. Persiapan belajar dapat dilakukan dengan cara mempelajari/membaca materi modul, merangkum, dan membuat catatan atau menyiapkan pertanyaan tentang materi belajar yang belum jelas. Melalui cara ini, peserta tutorial akan berperan aktif dan memanfaatkan kegiatan tutorial secara optimal dalam upaya mencapai kompetensi mata kuliah yang ditutorialkan (Katalog Program Pendas, 2010). Sejalan dengan itu, mahasiswa yang mengalami kesulitan belajar akan dapat meminta bantuan tutor pada kesempatan TTM atau di luar waktu tutorial (Munir, 2009).

Sampai saat ini, bahan ajar dalam kemasan modul tercetak (printed modul) masih memegang peranan sentral dalam penyampaian materi sistem pembelajaran jarak jauh, karena itu modul belajar harus senantiasa ditingkatkan kualitasnya, baik dari segi isinya maupun kemasannya (Pribadi, Puspitasari, \& Hanafi, 2005). Bahan ajar memegang peranan penting dalam transfer pengetahuan, sedangkan bahan ajar utama yang digunakan UT saat ini adalah bahan ajar cetak yang disebut Buku Materi Pokok (BMP) yang yang dikemas dalam bentuk modul (Katalog UT, 2011). Lebih lanjut dikemukakan bahwa bahan ajar untuk belajar mandiri dirancang secara khusus agar mudah dipelajari secara mandiri oleh mahasiswa, sesuai dengan tujuan instruksional yang ingin dicapai dari mata kuliah yang bersangkutan. Universitas Terbuka dalam memilih bahan ajar cetak sebagai sarana utama dalam menyampaikan materi perkuliahan berdasarkan pertimbangan bahwa bahan ajar cetak relatif murah, mudah biaya pengembangan dan produksinya (Pribadi, Puspitasari, \& Hanafi, 2005).

Program Studi S1 PGSD di Universitas Terbuka merupakan salah satu program jenjang pendidikan dasar yang menyelenggarakan pendidikan dalam jabatan (in-service training) yang bertujuan untuk meningkatkan mutu dan kualifikasi guru kelas SD (Katalog Program Pendas, 2010), sehingga persayaratan calon mahasiswa yang akan menjadi mahasiswa program studi S1 PGSD harus sudah menjadi guru SD/MI. Lebih lanjut dikemukakan bahwa dalam Program Studi S1 PGSD diselenggarakan tutorial tatap muka untuk memberikan bantuan dan bimbingan belajar kepada mahasiswa yang bertujuan untuk memicu dan memacu proses belajar mandiri. Dengan mengikuti tutorial, mahasiswa diharapkan akan terbantu dalam mengatasi permasalahan serta memantapkan dan menguasai kompetensi mata kuliah yang ditutorialkan.

Mata kuliah yang disediakan untuk TTM adalah mata kuliah berpraktik maupun mata kuliah yang tidak berpraktik tetapi memiliki kesulitan tinggi (Katalog Program Pendas, 2010). Kriteria mata kuliah yang dilengkapi layanan turorial adalah (i) mata kuliah yang berisi kompetensi utama program (core comptenecy), (ii) mata kuliah yang menuntut praktek, dan (iii) mata kuliah yang memiliki tingkat kompleksitas tinggi. Salah satu mata kuliah S1 PGSD yang tidak berpraktik tetapi disiapkan tutorialnya adalah Pembelajaran Matematika SD/PDGK4406 yang digunakan pada Semester 8 
(delapan). Selain memiliki kompleksitas tinggi, mata kuliah ini juga berisi kompetensi utama program (core competency).

Pelaksanaan kegiatan tutorial tatap muka untuk mahasiswa S1 PGSD dirancang untuk delapan kali pertemuan, sehingga tidak semua kompetensi dan materi kuliah dapat dibahas dalam tutorial. Dalam kegiatan tutorial hanya membahas dan mendiskusikan hal-hal yang dianggap sulit dan sangat penting dikuasai mahasiswa. Sehingga materi yang dibahas dalam kegiatan tutorial menyangkut (i) masalah yang ditemukan mahasiswa dalam mempelajari modul, (ii) kompetensi atau konsep esensial mata kuliah, (iii) persoalan yang terkait dengan unjuk kerja (praktek/praktikum) mahasiswa di dalam/di luar kelas tutorial, dan (iv) masalah yang berkaitan dengan profesi keguruan yang ditemukan ketika menjalankan tugas sehari-hari (Katalog Program Pendas. 2010).

Dalam kegiatan tutorial tatap muka, keberhasilan belajar mahasiswa PGSD UT dipengaruhi oleh berbagai komponen yang satu dengan yang lain saling berhubungan, diantaranya adalah kualitas bahan ajar, kinerja tutor dan motivasi belajar mahasiswa itu sendiri. Bahan ajar atau yang dikenal dengan modul sebagai materi pembelajaran mandiri harus memiliki kualitas yang baik dan memenuhi kriteria mudah dibaca dan dicerna, dengan pengertian mempunyai tingkat keterbacaan yang tinggi, melalui penggunaan bahasa yang sederhana, komunkatif dan jelas (Munir 2009). Sedangkan seorang tutor dengan memiliki kompetensi atau kecakapan dalam mempersiapkan dan mengelola kegiatan tutorial akan menimbulkan kinerja unggul. Kinerja unggul berarti tingkat pencapaian dalam situasi kerja (Yamin \& Maisah, 2010). Kinerja tutor tidak lepas dari kemampuan dalam merencanakan tutorial dalam bentuk Rancangan Aktivitas Tutorial (RAT) dan Satuan Acara Tutorial (SAT) serta penguasaan kemampuan delapan keterampilan dasar tutorial. Dengan demikian tutor yang memiliki kemampuan merencanakan tutorial dan menguasai kemampuan delapan keterampilan dasar tutorial, maka akan menimbulkan tingkat pencapaian hasil kerja yang unggul dalam kegiatan tutorial. Tutor yang memiliki kinerja yang unggul sangat diperlukan untuk membimbing mahasiswa yang mengikuti tutorial tatap muka, khususnya tutorial mata kuliah Pembelajaran Matematika SD.

Motivasi dari mahasiswa sangat diperlukan dalam menunjang belajar mandiri yang menuntut inisiatif sendiri untuk mempelajari bahan ajar, mengerjakan tugas-tugas, mengerjakan latihan-latihan yang terdapat dalam Buku Materi Pokok (BMP). Dalam berbagai hasil penelitian mengenai motivasi belajar ditemukan kesimpulan sebagai berikut; Tingkat motivasi belajar cenderung berkorelasi positif dengan hasil belajar, artinya semakin kuat/tinggi tingkat motivasi belajar, semakin tinggi hasil belajarnya. Demikian pula hasil belajar yang baik nampaknya juga berpengaruh terhadap hasil belajar berikutnya (Suciati, 2003). Sanjaya (2009) mengemukakan bahwa keberhasilan belajar siswa dapat ditentukan oleh motivasi belajar yang dimilikinya. Siswa yang memiliki motivasi belajar tinggi cenderung prestasinyapun akan tinggi pula.

Tujuan penulisan artikel ini adalah menjelaskan tentang pemahaman konsep bilangan bulat para guru SD peserta Pendidikan Guru SD - Universitas Terbuka ditinjau dari aspek modul sebagai bahan belajar utama, kinerja tutor sebagai pelaksana layanan bantuan belajar dan motivasi belajar mahasiswa praktisi belajar mandiri. Penelitian dilaksanakan terhadap mahasiswa PGSD-UT dari Kelompok Belajar Pasir Jambu Kabupaten Bandung di Wilayah Kerja UPBJJ Bandung masa registrasi 2012.1. 


\section{METODOLOGI}

Penelitian dengan pendekatan kuantitatif ini menggunakan metode deskriptif-analitis dan metode survai dalam proses pengumpulan data. Variabel penelitian adalah kualitas modul $\left(X_{1}\right)$, kinerja tutor $\left(X_{2}\right)$, dan motivasi belajar $\left(X_{3}\right)$ sebagai variabel independen, dan pemahaman konsep $(Y)$ sebagai variabel dependen.

Sampel adalah 72 peserta tutorial mata kuliah Pembelajaran Matematika SD dari Kelompok Belajar Desa Pasir Jambu, Kabupaten Bandung masa registrasi 2012.1. Pengumpulan data dilaksanakan menggunakan kuesioner, observasi, tes untuk tutor, dan studi dokumentasi. Peserta tutorial diberi 3 (tiga) set kuesioner tentang kualitas modul, kinerja tutor dan motivasi belajar mahasiswa dan 1 (satu) set untuk tes pemahaman konsep bilangan bulat. Tutor diberi tes kemampuan pemahaman konsep bilangan bulat. Selain itu, wawancara dan observasi dilakukan terhadap aktivitas pembelajaran selama program tutorial berlangsung selama satu periode masa registrasi.

Data dianalisis menggunakan metode Korelasi Pearson Product Moment, menghitung prediksi persamaan regresi dengan rumus $\hat{Y}=a+b X$, dan regresi ganda untuk mencari hubungan antar dua variabel atau lebih secara simultan dengan menggunakan rumus $\hat{Y}=\beta_{0}+\beta_{1} X_{1}+\beta_{2} X_{2}+\ldots$. $+\beta_{k i} X_{k i}+€$. Untuk menguji hipotesis digunakan Uji-t dengan taraf $\alpha=5 \%$.

\section{HASIL DAN PEMBAHASAN \\ Pemahaman Konsep}

Berdasarkan hasil pengumpulan data tentang pemahaman konsep bilangan bulat terhadap mahasiswa PGSD Universitas Terbuka Pokjar Pasir Jambu Kabupaten Bandung di Wilayah Kerja UPBJJ Bandung, kemudian dihitung dengan SPSS dan angka persentase, selanjutnya dikonsultasikan dengan Kriteria Interpretasi Skor pada Tabel 1, maka variabel pemahaman konsep termasuk kedalam kriteria Kuat (76,42\%).

Tabel 1. Kriteria Interpretasi Skor

\begin{tabular}{cc}
\hline Presentase Skor & Kriteria Keberhasilan \\
\hline $0 \%-19,99 \%$ & Sangat Lemah \\
$20 \%-39,99 \%$ & Lemah \\
$40 \%-59,99 \%$ & Cukup \\
$60 \%-79,99 \%$ & Kuat \\
$80 \%-100,00 \%$ & Sangat Kuat \\
\hline
\end{tabular}

(Riduwan, 2005)

\section{Kualitas Modul}

Hasil analisis menggunakan persentase yang dikonsultasikan dengan kriteria interpretasi skor seperti pada Tabel 1, maka variabel kualitas modul termasuk Sangat Kuat/Tinggi (80,49\%). Dari hasil pengolahan data dengan mengunakan SPSS untuk melihat prediksi persamaan regresinya dengan bentuk $\hat{Y}=1,070+0,194 X_{1}$. Dengan nilai Sig sebesar 0,000 . Karena tarap nyata $a=5 \%$, ternyata nilai $0,000<0,05$. Dengan demikian maka prediksi persamaan regresi yang diperoleh itu berarti..

Besarnya kontribusi kualitas modul digunakan indeks determinasi, yaitu sebesar $(0,519)^{2}=$ 0,269 , atau koefisien determinasi sebesar $26,90 \%$. Sehingga diketahui bahwa sebesar $26,90 \%$ 
pemahaman konsep bilangan bulat ditentukan oleh kualitas modul, dan sisanya 73,10\% pemahaman konsep bilangan bulat tersebut ditentukan oleh variabel di luar kualitas modul. Selanjutnya untuk mengetahui signifikansi kualitas modul berkontribusi terhadap pemahaman konsep, hasil pengolahan data diperoleh besar korelasi antara kontribusi kualitas modul dengan pemahaman konsep sebesar 0,519 dan uji t sebesar 4,932. Kemudian dibandingkan dengan Tabel Distribusi t dengan tarap nyata $a=5 \%$, diperoleh 4,932 >1,998, maka Ho ditolak artinya signifikan. Sehingga dapat disimpulkan bahwa kualitas modul berkontribusi secara signifikan terhadap pemahaman konsep bilangan bulat oleh mahasiswa PGSD Universitas Terbuka Pokjar Pasir Jambu Kabupaten Bandung.

Kontribusi kualitas modul Pembelajaran Matematika SD/PDGK4406 dikatakan termasuk cukup tinggi, hal ini sesuai dengan hasil studi dari Supardi (2001) dalam Herman (2001) menyimpulkan bahwa buku pelajaran berkontribusi sekitar 75\% terhadap keberhasilan pembelajar. Juga sejalan dengan Maulana salah satu pakar Kebijakan Bisnis dari IPB menyatakan bahwa tentang kualitas bahan ajar UT terutama dilihat substansinya. Dari sisi substansinya, bahan ajar yang berkualitas adalah bahan ajar yang memiliki ketepatan tingkat kompetensi yang dipersyaratkan, keakuratan dan kelengkapan materi, sistematisasi penulisan yang baik, serta kejelasan dan keterbacaan (Nasution ,2010). Hasil penakaran menunjukkan, tahun 2008 rata-rata bahan ajar, baik dilihat dari kualitas setiap modul maupun keseluruhan, berada pada kategori bagus (Widaningsih, 2010). Faktor yang mendasari meningkatnya kualitas modul karena Universitas Terbuka dalam mengembangkan bahan ajar cetak seragam dalam format yang standar dengan alasan atau rasional yang mendasari hal ini adalah untuk memudahkan UT dalam melakukan pengelolaan, baik dalam proses penembangan maupun dalam penggunaan bahan ajar (Pribadi \& Hanafi, 2007).

\section{Kinerja Tutor}

Berdasarkan hasil analisis terhadap dokumentasi tutor mata kuliah Pembelajaran Matematika SD Pokjar Pasir Jambu masa registrasi 2012.1 diperoleh gambaran bahwa tutor tersebut telah memiliki kriteria dan persyaratan sebagai tutor seperti yang yang ditetapkan oleh Universitas Terbuka. Hasil analisis dengan menggunakan angka persentase dari observasi tentang perencanaan tutorial yang berupa Rancangan Aktivitas Tutorial (RAT) dan Satuan Acara Tutorial (SAT) termasuk kedalam kriteria Kuat $(78,18 \%)$. Sedangkan hasil observasi terhadap pelaksanaan tutorial termasuk kriteria Kuat (72,00\%). Berdasarkan hasil analisis dari pengumpulan data dari tes terhadap pemahaman konsep materi bilangan bulat termasuk kedalam kriteria Cukup (45\%). Hasil analisis dari angket diperoleh gambaran pelaksanaan tutorial termasuk kriteria Sangat Kuat $(93,79 \%)$.

Hasil pengolahan data dengan menggunakan SPSS untuk melihat prediksi persamaan regresi dengan bentuk $\hat{Y}=6,946+0,159 X_{2}$, Dengan nilai Sig sebesar 0,000 . Karena tarap nyata $a=$ $5 \%$, ternyata nilai $0,000<0,05$. Dengan demikian maka prediksi persamaan regresi yang diperoleh itu berarti. Besarnya kontribusi kinerja tutor digunakan indeks determinasi, yaitu sebesar $(0,429)^{2}=$ 0,183 , atau koefisien determinasi sebesar $18,30 \%$. Sehingga diketahui bahwa sebesar 18,30\% pemahaman konsep bilangan bulat ditentukan oleh kinerja tutor, dan sisanya 81,70\% pemahaman konsep bilangan bulat tersebut ditentukan oleh variabel di luar kinerja tutor.

Untuk mengetahui kinerja tutor berkontribusi secara signifikan terhadap pemahaman konsep, hasil pengolahan data diperoleh besar korelasi antara kontribusi kinerja tutor dengan pemahaman konsep sebesar 0,429 dan uji t sebesar 3,855. Kemudian dibandingkan dengan Tabel Distribusi t dengan tarap nyata $a=5 \%$, diperoleh 3,855 > 1,998; maka Ho ditolak artinya signifikan. Sehingga 
dapat disimpulkan bahwa kinerja tutor berkontribusi secara signifikan terhadap pemahaman konsep bilangan bulat oleh mahasiswa PGSD Universitas Terbuka Pokjar Pasir Jambu Kabupaten Bandung.

Kinerja tutor secara umum termasuk kriteria cukup karena berbagai alasan, seperti (i) menyusun perencanaan tutorial berupa RAT-SAT, (ii) mengecek kesiapan mahasiswa mengikuti tutorial, (iii) mengelola interaksi dalam kegiatan tutorial dengan menangapi dan memberikan respon atau jawaban yang positif, menggunakan ekspresi lisan, tulisan yang mudah dibaca, dan memberikan isyarat gerakan badan secara efektif, serta adanya kelancaran berbicara, (iv) bersikap terbuka dan luwes serta membantu mengembangkan sikap positif kepada mahasiswa untuk belajar, mengembangkan hubungan antar pribadi yang sehat dan serasi, memberi perhatian khusus dengan memberikan tanggapan, bimbingan belajar dan membantu komunikasi antar mahasiswa, (v) membantu memperjelas pemahaman mahasiswa atas sebuah konsep, (vi) memberikan penilaian akhir dengan tanya jawab, (vii) melaksanakan kegiatan penutup, dan (viii) mengunakan bahasa Indonesia secara lisan dengan ucapan yang jelas, lancar, sopan dan tata bahasa baku.

Hal yang mempengaruhi pemahaman konsep oleh tutor termasuk kriteria cukup karena faktor kekurangsiapan tutor dalam melaksanakan tutorial terutama dalam penguasaan pemahaman konsep materi bilangan bulat. Sedangkan penelitian yang dilakukan Herman (2010) menyatakan bahwa tutor tampaknya tidak memiliki persoalan pada penguasaan materi tutorial, Jadi tutor yang terpilih memang memiliki kompetensi materi ajar yang baik.

\section{Motivasi Belajar}

Hasil analisis dengan menggunakan angka persentase diperoleh gambaran bahwa motivasi belajar mahasiswa termasuk kriteria sangat kuat (85,67\%). Hasil pengolahan data dengan menggunakan SPSS diperoleh $\hat{Y}=-4,784+0,270 X_{3}$, dengan nilai Sig sebesar 0,000. Pada taraf nyata $\alpha=5 \%$, ternyata nilai $0,000<0,05$, maka prediksi persamaan regresi yang diperoleh berarti.

Besarnya kontribusi motivasi belajar mahasiswa digunakan indeks determinasi, yaitu sebesar $(0,546)^{2}=0,298$, atau koefisien determinasi sebesar $29,80 \%$. Sehingga diketahui bahwa $29,80 \%$ pemahaman konsep bilangan bulat ditentukan oleh motivasi belajar mahasiswa, dan sisanya 70,20\% pemahaman konsep bilangan bulat tersebut ditentukan oleh variabel di luar motivasi belajar mahasiswa. Untuk mengetahui signifikansi motivasi belajar mahasiswa berkontribusi terhadap pemahaman konsep, hasil pengolahan data diperoleh besar korelasi antara kontribusi motivasi belajar mahasiswa dengan pemahaman konsep sebesar 0,546 dan Uji t sebesar 5,296. Kemudian dibandingkan dengan Tabel Distribusi t dengan tarap nyata $\alpha=5 \%$, diperoleh 5,296 $>1,998$, maka Ho ditolak artinya signifikan. Sehingga dapat disimpulkan bahwa motivasi belajar mahasiswa berkontribusi secara signifikan terhadap pemahaman konsep bilangan bulat oleh mahasiswa PGSD UT Pokjar Pasir Jambu Kabupaten Bandung

Hasil penelitian ini sejalan dengan McClelland, Sfenrianto (dalam Noviyanti, 2011) yang menjelaskan bahwa motivasi belajar mempunyai kontribusi sampai $64 \%$ terhadap hasil belajar. Hasil penelitian oleh Noviyanti (2011) menjelaskan bahwa motivasi berpengaruh terhadap prestasi belajar. Kaitan dalam pengaruh motivasi belajar terhadap prestasi belajar Slamet (2003) mengemukakan bahwa motivasi erat hubungannya dengan tujuan yang akan dicapai dalam belajar, didalam menentukan tujuan itu dapat disadari atau tidak, akan tetapi untuk mencapai tujuan itu perlu berbuat, sedangkan yang menjadi penyebab berbuat adalah motivasi itu sendiri sebagai daya penggerak atau pendorongnya. 
Hal ini pun yang menjadi faktor meningkatnya motivasi belajar mahasiswa mengikuti tutorial sejalan dengan persyaratan menjadi pendidik seperti yang tertuang dalam PP No. 19/2005 tentang Standar Nasional Pendidikan Bab VI Standar Pendidik dan Tenaga Kependidikan Pasal 29 Ayat (2). Pendidik pada SD / MI atau yang sederajat memiliki kualifikasi akademik pendidikan minimum Diploma IV) atau Sarjana Strata 1 ( S1).

\section{Kontribusi Kualitas Modul dan Kinerja Tutor terhadap Pemahaman Konsep}

Berdasarkan hasil analisi data untuk melihat prediksi persamaan regresi dengan bentuk $\hat{Y}=$ $-7,643+0,165 X_{1}+0,119 X_{2}$. Dengan nilai Sig sebesar 0,000. Karena tarap nyata $a=5 \%$, ternyata nilai $0,000<0,05$. Dengan demikian maka prediksi persamaan regresi yang diperoleh masuk kategori berarti. Besarnya kontribusi kualitas modul dan kinerja tutor yang merupakan gabungan dari hasil koeffisien dan korelasi atau digunakan indeks determinasi, yaitu sebesar $(0,606)^{2}=0,367$, atau koefisien determinasi sebesar $36,70 \%$. Sehingga diketahui bahwa sebesar $36,70 \%$ pemahaman konsep bilangan bulat ditentukan oleh kualitas modul dan kinerja tutor, dan sisanya $63.70 \%$ pemahaman konsep bilangan bulat tersebut ditentukan oleh variabel di luar kualitas modul dan kinerja tutor. Selanjutnya untuk mengetahui signifikansi kualitas modul dan kinerja tutor berkontribusi terhadap pemahaman konsep, hasil pengolahan data diperoleh besar korelasi antara kontribusi motivasi belajar mahasiswa dengan pemahaman konsep sebesar 0,606 dan uji t sebesar 6,1890.

Kemudian dibandingkan dengan Tabel Distribusi t dengan tarap nyata $a=5 \%$, diperoleh $6,1890>1,998$, maka Ho ditolak artinya signifikan. Sehingga dapat disimpulkan bahwa kualitas modul dan kinerja tutor berkontribusi secara signifikan terhadap pemahaman konsep bilangan bulat oleh mahasiswa PGSD Universitas Terbuka Pokjar Pasir Jambu Kabupaten Bandung. Dengan melihat kontribusi kualitas modul dan kinerja tutor terhadap pemahaman konsep sebesar 36,70\%, hal ini menunjukkan bahwa apabila ingin meningkatkan pemahaman konsep oleh mahasiswa lebih tinggi lagi, maka diperlukan peningkatan lagi dari kontribusi secara bersama antara kualitas modul dan kinerja tutor.

\section{Kontribusi Kinerja Tutor dan Motivasi Belajar terhadap Pemahaman Konsep}

Berdasarkan hasil pengolahan data untuk melihat prediksi persamaan regresi dengan bentuk $\hat{Y}=-11,944+0,113 X_{2}+0,229 X_{3}$. Dengan nilai Sig sebesar 0,000 . Karena tarap nyata $a=5 \%$, ternyata nilai $0,000<0,05$. Dengan demikian maka prediksi persamaan regresi yang diperoleh itu berarti.

Besarnya kinerja tutor dan motivasi belajar mahasiswa yang merupakan gabungan dari hasil koeffisien dan korelasi atau digunakan indeks determinasi, yaitu sebesar $(0,619)^{2}=0,383$, atau koefisien determinasi sebesar 38,30\%. Sehingga diketahui bahwa sebesar 38,30\% pemahaman konsep bilangan bulat ditentukan oleh kinerja tutor dan motivasi belajar mahasiswa, dan sisanya $61,70 \%$ pemahaman konsep bilangan bulat tersebut ditentukan oleh variabel di luar kinerja tutor dan motivasi belajar mahasiswa. Untuk mengetahui signifikansi kinerja tutor dan motivasi belajar mahasiswa berkontribusi terhadap pemahaman konsep, hasil pengolahan data diperoleh besar korelasi antara kontribusi kinerja tutor dan motivasi belajar mahasiswa dengan pemahaman konsep sebesar 0,619 dan Uji t sebesar 6,4029. Kemudian dibandingkan dengan Tabel Distribusi t dengan tarap nyata $\alpha=5 \%$, diperoleh 6,4029 >1,998; maka Ho ditolak artinya signifikan. Sehingga dapat disimpulkan bahwa kinerja tutor dan motivasi belajar mahasiswa berkontribusi secara signifikan 
terhadap pemahaman konsep bilangan bulat oleh mahasiswa PGSD UT peserta Kelompok Belajar Desa Pasir Jambu Kabupaten Bandung.

Kontribusi secara bersama dari kinerja tutor dan motivasi belajar mahasiswa terhadap pemahaman konsep oleh mahasiswa sebesar 38,30\%, menunjukkan adanya peningkatan kontribusi secara bersama dari dua kontribusi antara kualitas modul dan kinerja tutor, sehingga untuk meningkatkan pemahaman konsep oleh mahasiswa diperlukan lagi pengingkatan kontribusi secara bersama dari kinerja tutor dan motivasi belajar mahasiswa.

\section{Kontribusi Kualitas Modul, Kinerja Tutor dan Motivasi Belajar Mahasiswa terhadap Pemahaman Konsep}

Hasil pengolahan data dengan menggunakan SPSS untuk melihat prediksi persamaan regresi dengan bentuk $\hat{Y}=-22,026+0,141 X_{1}+0,085 X_{2}+0,200 X_{3}$, Dengan nilai Sig sebesar 0,000. Karena tarap nyata $\alpha=5 \%$, ternyata nilai $0,000<0,05$. Dengan demikian maka prediksi persamaan regresi yang diperoleh berarti. Besarnya kontribusi kualitas modul, kinerja tutor dan motivasi belajar mahasiswa merupakan gabungan dari hasil koefisien dan korelasi atau digunakan indeks determinasi, yaitu sebesar $(0,718)^{2}=0,516$, atau koefisien determinasi sebesar $51,50 \%$, yang merupakan gabungan dari kontribusi dari kualitas modul sebesar 19,62\%, kinerja tutor sebesar 9,78\% dan motivasi belajar sebesar 22,11\%. Sehingga diketahui bahwa sebesar 51,50\% pemahaman konsep bilangan bulat ditentukan oleh kualitas modul, kinerja tutor dan motivasi belajar mahasiswa, sedangkan sisanya 48,50\% pemahaman konsep bilangan bulat tersebut ditentukan oleh variabel di luar kualitas modul, kinerja tutor, dan motivasi belajar. Untuk mengetahui signifikansi kualitas modul, kinerja tutor, dan motivasi belajar mahasiswa berkontribusi terhadap pemahaman konsep, hasil pengolahan data diperoleh besar korelasi antara kontribusi kualitas modul, kinerja tutor dan motivasi belajar mahasiswa dengan pemahaman konsep sebesar 0,718 dan uji t sebesar 8,3803. Kemudian dibandingkan dengan Tabel Distribusi t dengan tarap nyata $\alpha=5 \%$, diperoleh 8,3803 >1,998; maka Ho ditolak artinya signifikan. Sehingga dapat disimpulkan bahwa kualitas modul, kinerja tutor dan motivasi belajar mahasiswa berkontribusi secara signifikan terhadap pemahaman konsep bilangan bulat oleh mahasiswa PGSD-UT Kelompok Belajar Desa Pasir Jambu Kabupaten Bandung.

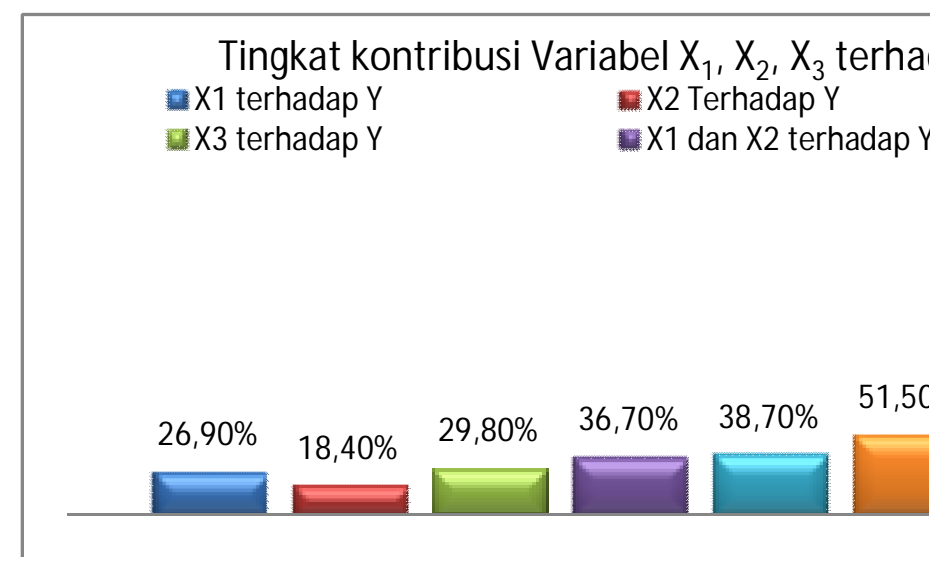

Gambar 1. Histogram tingkat kontribusi variabel $X_{1}, X_{2}, X_{3}$ terhadap $Y$ 
Melihat perbandingan besarnya kontribusi dari ketiga variabel, ternyata motivasi belajar mahasiswa yang paling tinggi yaitu sebesar 22,11\%, kualitas modul sebesar 19,62\%, dan kinerja tutor yang paling rendah sebesar $9,78 \%$, dan sisanya 48,50\% merupakan faktor yang berpengaruh di luar variabel penelitian, seperti (i) kemandirian belajar merupakan salah satu prediktor keberhasilan belajar, dan berkontribusi terhadap hasil belajar sebesar 63,91\% (Irzan \& Enceng, 2006), (ii) usia dan gender, dimana secara semua mahasiswa berusia lebih dari 55 tahun mempunyai tingkat kegiatan belajar mengajar yang tinggi dari skor yang diperoleh kelompok mahasiswa lain, dan skor mahasiswa perempuan sedikit lebih tinggi dibandingkan skor mahasiswa laki-laki (Islam, 2010), (iii) penggunaan multimedia sangat berpengaruh terhadap efektivitas belajar mandiri. Secara umum faktor yang mempengaruhi prestasi belajar adalah faktor dari dalam diri mahasiswa (intern) seperti faktor jasmani; faktor kesehatan dan cacat tubuh, faktor psikologis; intelegensi, bakat, dan kesiapan serta faktor kelelahan, faktor dari luar mahasiswa (ekstern) seperti faktor keluarga, sekolah dan faktor masyarakat. Model visual tingkat kontribusi variabel $X_{1}, X_{2}, X_{3}$ terhadap $Y$ dapat dilihat pada Gambar1.

Dari gambar histogram pada Gambar 1 tentang tingkat kontribusi variabel $\mathrm{X}_{1}, \mathrm{X}_{2}, \mathrm{X}_{3}$ terhadap $Y$ terlihat bahwa (1) kontribusi yang paling tinggi terhadap pemahaman konsep bilangan bulat oleh mahasiswa PGSD Universitas Terbuka Pokjar Pasir Jambu Kabupaten Bandung di Wilayah Kerja UPBJJ Bandung yaitu kontribusi secara bersama dari kualitas modul, kinerja tutor dan motivasi belajar mahasiswa sebesar $51.50 \%$, (2) kontribusi secara bersama kinerja tutor dan motivasi belajar mahasiswa terhadap pemahaman konsep bilangan bulat oleh mahasiswa sebesar $38.40 \%$, (3) kontribusi secara bersama dari kinerja tutor dan motivasi belajar mahasiswa terhadap pemahaman konsep bilangan bulat oleh mahasiswa sebesar 36,70\%, (4) kontribusi motivasi belajar mahasiswa terhadap pemahaman konsep bilangan bulat oleh mahasiswa sebesar 29,80 \%, (5) kontribusi dari kualitas modul terhadap pemahaman konsep bilangan bulat oleh mahasiswa sebesar $26,90 \%$, dan (6) kontribusi dari kinerja tutor terhadap pemahaman konsep bilangan bulat oleh mahasiswa sebesar $18,30 \%$.

Dari hasil penelitian ini menunjukkan bahwa untuk meningkatkan pemahaman konsep bilangan bulat oleh mahasiswa diperlukan kontribusi secara bersama dari kualitas modul, kinerja tutor dan motivasi belajar mahasiswa itu sendiri.

\section{KESIMPULAN DAN SARAN}

Hasil penelitian menunjukkan bahwa (i) kualitas modul berkontribusi secara signifikan terhadap pemahaman konsep bilangan bulat sebesar $26,90 \%$, (ii) kinerja tutor berkontribusi secara signifikan terhadap pemahaman konsep bilangan bulat sebesar 18,30\%, (iii) motivasi belajar mahasiswa berkontribusi secara signifikan terhadap pemahaman konsep sebesar 29,80\%, (iv) kualitas modul dan kinerja tutor berkontribusi secara bersama dan signifikan terhadap pemahaman konsep sebesar 36,70\%, (v) kinerja tutor dan motivasi belajar berkontribusi secara bersama dan signifikan terhadap pemahaman konsep sebesar 38,30\%, (vi) kualitas modul, kinerja tutor dan motivasi belajar mahasiswa berkontribusi secara bersama dan signifikan terhadap pemahaman konsep sebesar 51,50\%, yang merupakan kontribusi dari kualitas modul sebesar 19,62\%, kinerja tutor 9,78\% dan kontribusi motivasi belajar mahasiswa sebesar 22,11\%, dan (vii) sisanya 48,50\% ditentukan oleh variabel lain di luar kualitas modul, kinerja tutor dan motivasi belajar mahasiswa.

Disarankan agar penyelenggara tutorial mahasiswa (i) mempertahankan dan meningkatkan kualitas modul bagi penyelenggara tutorial ddalam upaya meningkatkan kualitas belajar mandiri, yaitu 
dengan mengembangkan modul elektronik sesuai dengan perkembangan teknologi informasi, (ii) meningkatkan profesionalitas tutor, baik di bidang penguasaan teknologi informasi maupun penguasaan materi belajar dalam upaya meningkatkan kemampuan mahasiswa peserta tutorial dalam pemahaman konsep-konsep ilmu yang ditutorialkan, (iii) meningkatkan motivasi belajar peserta tutorial melalui perbaikan sistim pelayanan bantuan belajar yaitu membangun komunikasi yang intens antara tutor dengan tutee, (iv) melanjutkan penelitian terhadap variabel-variabel yang belum diteliti yang memberikan kontribusi terhadap pemahaman konsep, atau memperluas wilayah penelitian dalam rangka meningkatkan kontribusi kualitas modul, kinerja tutor dan motivasi belajar mahasiswa terhadap pemahaman konsep oleh mahasiswa PGSD Universitas Terbuka.

\section{REFERENSI}

Herman, (2010). Penilaian peserta terhadap kinerja tutor, dan hasil tutorial dan biaya tutorial pada tutorial tatap muka di Universitas Terbuka. [Online] Diambil tanggal 26 April 2012., dari www.lppm.ut.ac.id/... /84-98\%20PTJJ\%2011 (2)\%202010\%20\%20He.

Herman, T. (2002). Pengembangan buku ajar matematika SMU untuk meninkatkan kemampuan pemecahan masalah dan komunikasi matematis siswa. Proposal Penelitian, Jurusan Pendidikan Matematika. FPMIPA, Universitas Pendidikan Indonesia.

Islam, S.. (2010). Kesiapan belajar mandiri mahasiswa UT dan siswa SMA untuk belajar dengan sistem pendidikan terbuka dan jarak jauh di Indonesia. Jakarta. Jurnal Pendidikan Terbuka dan Jarak Jauh. 11(1), 1-14.

Munir. (2009). Pembelajaran jarak jauh, berbasis teknologi informasi dan komunikasi. Bandung: Alfabeta.

Nasution, L. (2010). Bahan ajar UT memiliki kualitas tinggi. Diambil tanggal 26 April 2012. dari http://sarjana3tahunlul.us/index.php?option=com content\&task= view\&id =107\&ltemid=2.

Noviyanti, M. (2011). Pengaruh motivasi dan keterampilan berkomunikasi terhadap prestasi belajar mahasiswa pada tutorial online berbasis pendekatan kontekstual pada mata kuliah statistika pendidikan. Jakarta. Jurnal Pendidikan, 12(2), 80-80.

Riduwan. (2005). Skala pengukuran variabel-variabel penelitian. Cetakan ke 4, Bandung: Alfabeta.

Sanjaya, W. H. (2008). Kurikulum dan pembelajaran, teori dan praktik pengembangan kurikulum tingkat satuan pendidikan (KTSP), Jakarta: Kencana Prenada Media GroupSlameto. (2003). Belajar dan faktor-faktor yang mempengaruhinya. Jakarta. Rineka Cipta. Diambil pada tanggal 20-01-2012, dari http://aadesanjaya.blogspot.com/2011/02/prestasi-belajar.html.

Suciati et.al. (2003). Belajar dan pembelajaran 2. Jakarta: Universitas Terbuka.

Tahar, I.,\& Enceng. (2006). Hubungan kemandirian belajar dan hasil belajar pada pendidikan jarak jauh. Jurnal Pendidikan Terbuka dan Jarak Jauh, 7(2), 91-101.

Tim UT. (2010). Katalog program pendas, Edisi 2. Jakarta: Univeritas Terbuka. Undang-Undang Nomor 20 Tahun 2003 tentang Sistem pendidikan nasional.

Peraturan Pemerintah Republik Indonesia Nomor 19 Tahun 2005 tentang Standar nasional pendidikan.

Pribadi, B., \& Hanafi, H. (2007). Aplikasi pendekatan konstruktivisme pada bahan ajar sistem pendidikan jarak jauh, Jakarta. Jurnal Teknologi Pendidikan, 9(2).

Pribadi, B., Puspitasari, \& Hanafi. (2005). Implementasi jaminan kualitas dalam pengembangan bahan ajar di Universitas Terbuka. Jakarta. Jurnal Pendidikan Terbuka dan Jarak Jauh, 6(2), 92-102. 
Widiyaningsih, S. (2010). Bahan ajar UT memiliki kualitas tinggi. Diambil pada tanggal 26 April 2012, dari http://www.dikti.go.id/index.php?option=com content\&view=article\&id=1091:ut-makinberkualitas\&catid=69:berita-terkait\&ltemid= 196.

Yamin, M, \& Maisah. (2010). Standarisasi kinerja guru. Jakarta: Gaung Persada Press. 